\title{
The South African Heart Journal and the Protection of Personal Information Act
}

\section{Ntobeko A.B. Ntusi",\#,t}

*Division of Cardiology, Department of Medicine, University of

Cape Town and Groote Schuur Hospital, Observatory,

Cape Town, South Africa

\# Hatter Institute for Cardiovascular Research in Africa, Faculty of

Health Sciences, University of Cape Town, Cape Town, South Africa tCape Universities Body Imaging Centre, Faculty of Health Sciences, University of Cape Town, Observatory, Cape Town, South Africa

Address for correspondence:

Prof Ntobeko Ntusi

Chair and Head: Department of Medicine

University of Cape Town and Groote Schuur Hospital

J46.53, Old Main Building

Groote Schuur Hospital

Main Road

Observatory

7925

South Africa

Email:

ntobeko.ntusi@uct.ac.za

The Protection of Personal Information Act 4 of 2018 (POPIA), which came into effect on I July 2021, applies to research activities that involve identifiable personal information of individuals or organisations. Considering the impact that research has on participants' right to privacy is not just a POPIA obligation, it is also an integral part of research ethics and conduct. The South African Heart Journal takes information security seriously and urges all authors to consider prioritising this in all submissions. In turn, the Journal will endeavour to protect personal information of researchers as well as their research participants. The Journal commits to upholding research and publishing practices that always protect the identity of researchers and research participants (Table I).

Our advice to researchers is that:

all manuscripts submitted to the Journal must always contain de-identified information,

- researchers must collect as little personal information as possible,

- researchers must be transparent, and

researchers must always keep research data safe.

\section{FUNDING}

This article is not funded. Ntobeko Ntusi gratefully acknowledges funding from the National Research Foundation, South African Medical Research Council (MRC), UK MRC, and the Lily and Ernst Hausmann Trust

Conflict of interest: none declared.

TABLE I: POPIA principles and guidance for researchers.

\begin{tabular}{|c|c|c|}
\hline Principle & $\begin{array}{l}\text { Recommended action } \\
\text { by researchers }\end{array}$ & POPIA guidance \\
\hline $\begin{array}{l}\text { Information } \\
\text { de-identification }\end{array}$ & $\begin{array}{l}\text { - Collect anonymised } \\
\text { research data. } \\
\text { - De-identify data as } \\
\text { soon as possible. } \\
\text { - Mask the identity of } \\
\text { research participants } \\
\text { (pseudonymisation). }\end{array}$ & $\begin{array}{l}\text { - Part B, section I.I.2 of } \\
\text { the Code deals with } \\
\text { de-identification and } \\
\text { pseudonymisation. } \\
\text { - Practice must align } \\
\text { with institutional } \\
\text { policies and processes } \\
\text { for data anonymisation. }\end{array}$ \\
\hline $\begin{array}{l}\text { Collect as little } \\
\text { as possible }\end{array}$ & $\begin{array}{l}\text { - Be clear on why you } \\
\text { need to collect } \\
\text { personal information. } \\
\text { - Be clear about how } \\
\text { you will use personal } \\
\text { information in } \\
\text { research. } \\
\text { - Aim to always achieve } \\
\text { research goals without } \\
\text { using personal } \\
\text { information of } \\
\text { participants. }\end{array}$ & $\begin{array}{l}\text { - Part B, section } 7 \text { of the } \\
\text { Code deals with } \\
\text { minimal processing. }\end{array}$ \\
\hline Transparency & $\begin{array}{l}\text { - Research participants } \\
\text { must be well-informed } \\
\text { about the purpose of } \\
\text { the research and how } \\
\text { their personal details } \\
\text { are used and } \\
\text { protected. } \\
\text { - Ensure that systems } \\
\text { are in place to ensure } \\
\text { all members of the } \\
\text { research team can } \\
\text { protect the privacy of } \\
\text { research participants. }\end{array}$ & $\begin{array}{l}\text { - Part B, section } 9 \text { of the } \\
\text { Code deals with } \\
\text { POPIA's transparency } \\
\text { requirements. }\end{array}$ \\
\hline Data safety & $\begin{array}{l}\text { - Research data must be } \\
\text { kept and shared in a } \\
\text { secure manner. } \\
\text { - Institutional policies } \\
\text { for data safety must be } \\
\text { adhered to. } \\
\text { - Sensitive research data } \\
\text { must ideally be } \\
\text { encrypted. } \\
\text { - Secure data back-up } \\
\text { systems are essential. } \\
\text { - Restrict access to } \\
\text { identifiable personal } \\
\text { information to } \\
\text { researchers on a } \\
\text { "need to know" basis. }\end{array}$ & \\
\hline
\end{tabular}

